\title{
Balinese language ecology: Study about language diversity in tourism area at Ubud village
}

\author{
Ni Luh Sutjiati Beratha, Ni Wayan Sukarini, \\ I Made Rajeg \\ University of Udayana \\ Email: sutjiati59@gmail.com
}

\begin{abstract}
Ubud Village in Gianyar Regency is one of the tourism areas in Bali where Balinese people are bilingual because they have mastered more than one languages. In the environment of Balinese language, there also live other languages including national language (Indonesian) and foreign languages (such as English, Japanese, and Mandarin). Balinese people nowadays, especially in tourism area, have difficulties in using Balinese language so they use mixed languages, namely Balinese language with Indonesian language, with English language, or Mandarin. This phenomenon might indicate that Balinese language appears to be marginalized. This article aims at investigating languages that are used in Balinese language environment in Ubud. Qualitative method is applied with sociocultural approach, and theories related to the use of language are applied. The study shows that the marginalization of Balinese language appears to exist because there are various ethnic groups of immigrants who live in this village. The village of Ubud has already been occupied by expatriates who deliberately come to Bali and settle in Ubud. This effects the choice and use of a language.
\end{abstract}

Keywords: language ecology, marginalization, revitalization.

\begin{abstract}
Abstrak
Desa Ubud di Kabupaten Gianyar merupakan salah satu kawasan pariwisata dengan masyarakatnya yang berdwi bahasa karena umumnya mereka menguasai lebih dari satu bahasa. Dalam lingkungan bahasa Bali, digunakan juga bahasa nasional yaitu Bahasa Indonesia, bahasa asing seperti Bahasa Inggris, Jepang, dan Mandarin. Dewasa ini, khususnya di kawasan pariwisata, masyarakat Bali
\end{abstract}


mengalami kesulitan berbahasa Bali sehingga mereka menggunakan bahasa campuran, yakni Bahasa Bali dengan Bahasa Indonesia, Inggris, dan Mandarin. Fenomena ini menunjukkan bahwa Bahasa Bali tampaknya mulai termarginalkan. Artikel ini bertujuan untuk mengetahui bahasa-bahasa yang digunakan di lingkungan Bahasa Bali di Ubud. Metode kualitatif dengan pendekatan sosiokultural, dan teori-teori yang relevan dengan penggunaan bahasa digunakan dalam artikel ini. Hasil penelitian menunjukkan bahwa Bahasa Bali tampaknya termarginalkan karena adanya migrasi berbagai etnis yang menetap di Desa Ubud. Di samping itu, dewasa ini, Desa Ubud juga dipenuhi ekspatriat yang sengaja datang ke Bali dan menetap di Ubud. Ini yang memengaruhi pilihan bahasa.

Kata kunci: ekologi bahasa, marginalisasi, revitalisasi.

\section{Introduction}

$\mathbf{B}$ alinese children in general use Indonesian language to D communicate and rarely use Balinese language. This is due to the function of the Indonesian language as a national language. Furthermore, the Balinese language is considered very difficult by the children because it has speech level system. The refined Balinese language (bahasa Bali alus) is taught at schools, but children still find it difficult to use the language although the use of Balinese language is often socialized in local television channels. It should be noted that Balinese adults also have the same problem in using bahasa Bali alus so they use mixed languages, namely Balinese language mixed with Indonesian language or English language, especially villages which belong to tourism area (Keriana, 2004).

This is an obvious problem, namely the marginalization of Balinese language is related to the wide-spread use of Indonesian language. This condition may cause Balinese people to experience cultural and identity crisis, considering that Balinese language is a culture point and also an element of identity for Balinese people (Sutjiati Beratha, et.al, 2013:74). Moreover, the cultural tourism in Bali can experience degradation considering that Balinese culture is the main asset for the development, and this is useful for Balinese language revitalization program.

Language ecology is an interdisciplinary linguistic theory which explains about the dimension or space namely the physical 
aspect of geographical environment which becomes the place of life for all languages and the speakers (Mbete, 2013:2). This explanation shows that the language of Balinese ethnicity is Balinese language which exits ecologically in Bali island and other transmigration areas, namely Lampung (Sumatra), Palu (Sulawesi), and various places in Indonesia. In the environment of Balinese language, there also live the other languages such as the national language: Indonesian Language, foreign languages: English, Japanese, Mandarin, Korean, etc. Those languages are used to communicate and required by the community in their daily life.

Ubud Village in Gianyar Regency is one of the tourism areas in Bali where Balinese people are bilingual because they have mastered more than one languages. Balinese people use mixed languages namely Balinese - Indonesian, or Balinese - English (or other foreign languages). This phenomenon is an indication that Balinese language is being marginalized. One way to make Balinese language used in various contexts as it is the identity of Balinese culture, and to prevent it from being uprooted from the local culture is by knowing the Balinese language ecology. What languages are used in Balinese Language environment, since by tradition, ecological locality is very important to be explained beause it has strong relation to the sustainibility of the use of Balinese language (the language of Balinese ethnicity), and natural environment with its diversity.

The marginalization of Balinese Language is certainly a threat to the existence of Balinese Language in the society as it has been dominated by the use of foreign languages in this global era. This phenomenon is a threat to the existence of the local language and culture which at the time also threatens the natural environment with its diversity, although the Bali government has advised the head of Balinese Language Centre to preserve the Balinese language.

This article refers to language ecology by giving emphasis on languages which are used together by the people in Balinese Language environment in tourism area at Ubud Village. This topic will give positive contribution about deeper understanding so that the threat of Balinese Language marginalization can be discovered and the solution can be sought after. There are three parameters of language ecology either ecologically or linguistically. The three 
parameters are: (1) environment as an important factor of what languages (are spoken) are used in the environment (2) diversity which includes parts of environment either physically or mentally and (3) interrelation, interaction, and interdependence which cannot be separated from the environment and diversity parameter. The diversity in environment is certainly interrelated, interacted, and interdependent.

In relation to the use of language, the experts including Thompson (2007) and Althusser (2008) stated that ideology and interests will strongly determine our thoughts, attitude, and actions, including our thoughts, attitude, and actions in selecting the language that we use to communicate in various contexts, namely various social situations. In accordance with this opinion, in context of Balinese language marginalization, there is a discourse with the topic "The Needs of the Speakers are not Fulfilled, Balinese Language Becomes More and More Marginalized" (Bali Post, 13-102006 : 13). This means that the ideology and the interests of Balinese people are two things which significantly affect the preference (main choice) of language use in Balinese community. In this case, they do not prioritize the use of Balinese language, and prioritize more on the use of Indonesian language or foreign language, so the use of Balinese language is marginalized. This condition is certainly in process and has the implication in the daily life of Balinese people. There are several different concepts of ideology, one of them is explained by Takwin (2003:7), namely as a set of ideas which become the guidance for people to act in order to achieve a certain purpose. As stated by Althusser (2008), ideology in this context is basically a discourse, there is no discourse without ideology and there is no ideology without disourse. Discourse can be defined as a certain way to discuss and understand the world (Jorgensen dan Phillips, 2007: 2). Discourse in this context cannot be used without using a language, so the notion proposed by Aminuddin (2002: 29) is interesting toexplain in here, namely in this following quotation:

"disourse as the aim of study refers to the reality of language usage which is called as 'text'. Text as the concrete form of discourse is formed by sentences which have compositions, orders, and certain distribution characteristics." 
Based on the definition of ideology and discourse above, it can be understood that the use of language as a discourse cannot be separated from the ideology behind it. Therefore, exploring the relation between the use of language and ideology can be conducted by having close observation of the discourse (Thompson, 2007).

People talk by using language with a purpose. As stated by Althusser (2008), people use language in certain ways to get attention and to be followed by other people. Related to this, the use of language in such ways can reflect different social hierarchy. If the use of language is conducted by someone in a certain situation, it may have strength and certainty which other people do not have in different situation (Thompson, 2007: 77).

Using language, of course has certain purpose as stated by Althusser (2008). The purpose of people using language in such way is to get noticed and to be followed by others. In this regard, the use of language in this way can reflect the position of different social hierarchies. If a language is used by people in certain situations, it can give strength and certainty not a language use by others in other situations possesses (Thompson, 2007: 77).

Adhering to the idea about the relationship between ideology and the use of language can infer that people tend to mind the language use therefore the use gives them strength and certainty in achieving the goals, desires or interests. Therefore, the negligence of Balinese and the prioritization of Indonesian and foreign languages in the transformation of language use preferences among Balinese are suspected of having relation to their effort building strength and certainty in order to achieve goals, desires, and certain needs.

Based on post-colonial perspective, the phenomenon of language use is closely related to the modern concept in society. The people of Indonesia in general and Balinese people in particular who identify the advancement by global culture which one of the elements is the English (Atmadja, 2005: 49). On this basis and also considering Bali as renowned center of tourism development, and tourism is also a medium considered conducive for the development of global culture, so it can be presumed that Balinese has been possessed by the ideology of capitalism and consumtivism and hedonism. To put it into reality, they strive hard to obtain financial income as much as possible by cultivating/ adding and using all sorts of capital, including the intellectual capital in the form of 
language. In this context, Balinese people might prioritize English and other foreign languages than Balinese language, since by using foreign language they are more likely to communicate with potential parties in effort to obtain financial income.

Based on the background above, the main aim of this article is to explain that what languages are used by the people to communicate in Balinese language environment in tourism area at Ubud Village, Gianyar Regency.

\section{Method of writing the article}

This article used the data that was taken from in-depth interview conducted at Ubud village with key informants, i.e. in determining the people it needs the guidance from initial informants, that is the people who can give guidance about other individuals who understand various aspects of the life related to language use in the community (e.g. the village head, parents, etc). The information about the language choice and use given by the informants were gathered then analysed using qualitative method, and sociocultural approach, as well as theories of language use. The result of the analysis is presented narratively in the article.

\section{Parameters of language ecology}

There are three parameters of language ecology used in this article which include: 1. Environment parameter, 2. Diversity, and 3. Interrelation, interaction, and interdependene.The findings are explained and presented as follows.

\subsection{Environment parameter}

Ubud Village has a forest area which is very famous among international tourists. The forest area is called "Monkey Forest". This area is the place of conservation for animals and plants in there. There is one indigenous community to date that manages the forest in the village of Ubud, namely Pakraman Padang Tegal, the one that manages the Monkey Forest area. This is one of the leading attractions for visitors in the village of Ubud. In addition, the village of Ubud is also made up of pristine rice fields becoming one of the attractions for tourists who come to visit Ubud. Types of plant found in the village of Ubud are mostly banana, rambutan and orange. Although the village of Ubud is an area of tourism, but agriculture 
remains the main livelihood for most people of Ubud. Located in the heart of the district, Ubud consequently has sufficiently complete supporting infrastructure. The condition itself affects indirectly to the diversity patterns of livelihood or employment opportunities available for the people. In addition to the tourism and agriculture sectors, another sector the people of Ubud choose is trade sector. The sector is supported by the characteristics of Ubud as leading tourism destination in Gianyar regency. As a village located in the heart of the capital of Ubud district, the existence of a market as a media for buyers and sellers meeting contributes to the development of trade sector in Ubud, despite the presence of Ubud market is not automatically dominated by people of Ubud, nonetheless it would give quite significant effect to the economic growth of local people. The management of Ubud market itself is under the responsibility of the Government of Gianyar regency.

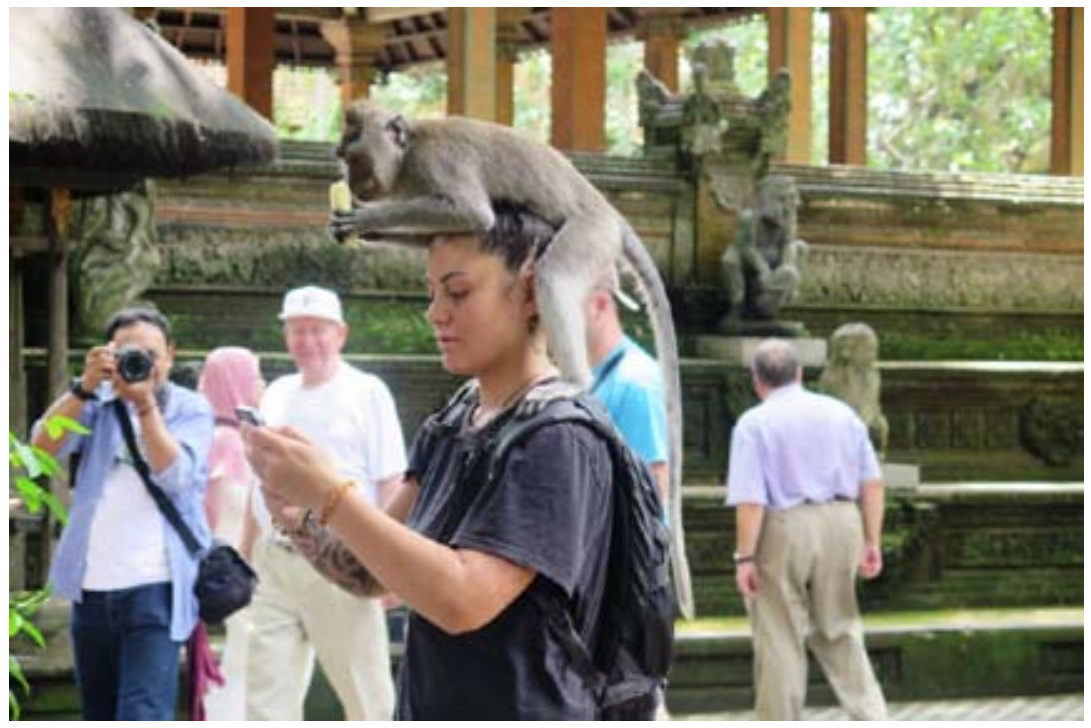

Figure 1. Monkey Forest at Ubud Village (Photo Darma Putra)

The society in every layer should take the development of tourism in Ubud gratefully. The beauty of its natural scenery, art, culture, custom and religious life of the people makes Ubud have appeal and then many tourists from various countries of the world come to visit. Panorama of Ubud with all its contents has great and perfect potency by the unification of tradition and culture as strong 
character of the people of Ubud.

Indigenous community or village called pakraman in Ubud Village also organizes pasraman ( schools for elementary students ranging from grade 4 to 6 only held on Sunday by pakraman village which aims to preserve the culture of Bali). A six villages in Ubud consisting of Ubud Pakraman village, Bentuyung Pakraman village, Junjungan Pakraman village, Tegallantang Pakraman village, Taman Kaja Pakraman village, and Padangtegal Pakraman village hold the pasraman regularly. In Pasraman, the children are taught skills related to the culture of Bali including maulat-ulatan ('knitting'), such as making various ketupat, klakat, , sanggah cucuk, canang, gebogan (kinds of equipments to prepare for the religious ceremony'), and etc. In addition, since the village of Ubud is one of tourism destinations in Bali, additional skills given are English and computers. Both of these skills are given to support tourism industry in this village.

According to the chief of Padang Tegal village 'Bendesa adat', Mr. I Made Gandra, SE. English lesson is taught by native speakers who stay in Ubud and will volunteer (without having paid monthly salary). Furthermore, Mr. I Made Gandra, SE says that computer and English skills are basic requirement for children so that they do not stutter in technology and can master English as an international language in global era. This is the right step in which the children are taught from early age to preserve Balinese culture and they get skills to support the growing tourism in the village.

Tourism development in Ubud villageisachieved by preserving the culture as a base to support tourism industry based on the norms prevailing in society with nuance of Hinduism inspiring arts and culture. By the increase in the quantity and quality of tourism activities, it is expected that the number of tourist visit in Ubud increases than before. Tourists coming to Ubud are indeed to enjoy Ubud arts and cultures. The unique art products offered have their own charm and need to get through integrated promotion and marketing. Cultural tourism is the tourism whose development and preservation use Balinese local culture animated by Hinduism with the greatness of national culture. Cultural Tourism contains the most dominant basic potential implying the goals for a reciprocal relationship between tourism and culture to occur, so that both of them develop in harmony and balance. 


\subsection{Diversity parameter}

Ubud is generally occupied by Balinese ethnic group. As it is described above already, since Ubud village is one of tourism areas in Bali and by the time the development of tourism in this village occurs, there are various ethnic group of immigrants who also live in this village. They are Chinese, Javanese, Sundanese, Sasak, Bugis, and others. In addition, nowadays the village of Ubud is already occupied by expatriates ( people who live temporarily or settle out of the country where they were born and raised, or in other words, people of foreign nationality living in Indonesia, usually because of governmental duty or profession), who deliberately come to Bali and settle in Ubud.

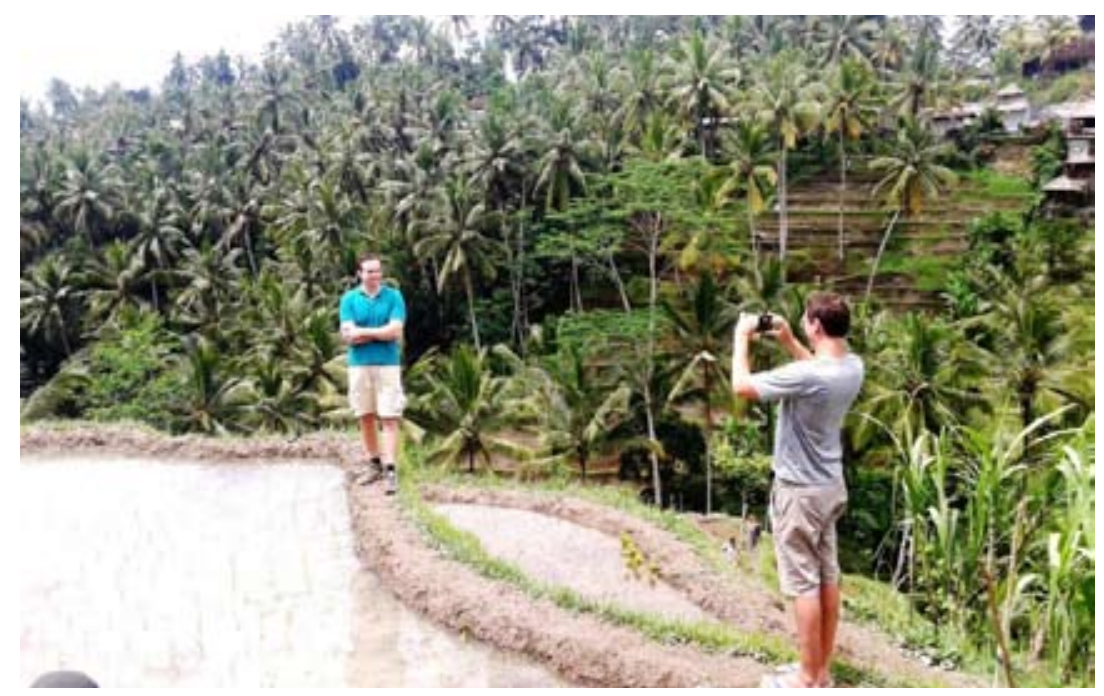

Figure 2. Rice field at Ceking Rice Terrace, near Ubud (Photo Fatrisia Yuliani)

The results of interviews conducted to informants show some reasons of why they to choose Ubud and settle there, they are (1) business they own in the field of tourism industry, (2) love for the village of Ubud, (3) beautiful nature of Ubud, (4) the people of Ubud who are very friendly, (5) Balinese arts and cultures, and (6) the occurrence of intermarriages between Balinese people in Ubud and foreigners (such as Italian, Australian, French, Spaniard, etc). This condition affects the choice and use of language. English becomes common choice of the language used by those mentioned as expatriates apart from other European languages such as 
Italian, French, and Spanish. In the context of tourism, English, Italian, French, and Spanish are very important because they are international languages, and these languages are used side by side with Balinese and Indonesian languages. This phenomenon causes Balinese language to be marginalized.

According to Ubud Tourist Information (2016), tourists visiting Ubud including from Africa, Argentina, Australia, USA, Austria, Netherlands, Belgium, Brazil, Canada, Chile, Denmark, Finland, Germany, Great Britain, Italy, Ireland, India, Japan, Colombia, Korea, Malaysia, Mexico, Norway, Philippines, France, New Zealand, China, Scotland, Spain, Sweden, Switzerland, Singapore, Thailand, Yugoslavia/ Serbia, and Greece. As a village located in the heart of the city subdistrict, logically, it is considered that it has quite sufficient supporting infrastructures. This condition itself affects indirectly to the diversity of patterns of livelihood or employment opportunities available for the people. In addition to the tourism and agriculture sectors, another sector people of Ubud choose is trade sector. The sector is supported by the characteristics of the village of Ubud as eminent tourism destination in Gianyar regency. As a village located in the heart of the capital of Ubud district, the existence of market functions as a media for buyers and sellers meeting and also contributes to the development of trade sector in Ubud, despite the existence of Ubud market is not automatically dominated by people of Ubud, nonetheless it remains affecting quite significantly to the economy growth of the local people. The management of Ubud market itself is under the responsibility of the Government of Gianyar regency.

\subsection{Interconnection, interaction, and interdependence}

In tourism areas in Bali, Balinese people seem to prefer using foreign languages to Balinese language. This condition is motivated by the dependence of Indonesia, including Bali in developed countries. As known, since October 13, 1994, by Law Number 7 year 1994 Indonesia has ratified the World Trade Organization agreements concerning on free trade system. Besides regionally APEC and AFTA emerge as trading blocs that promote free trade. As the consequence, not only locally but also nationally and internationally, the competition will be tighter, involving people from developed countries (Northern Countries) and developing countries or also called Third World 
Countries or Southern Countries.

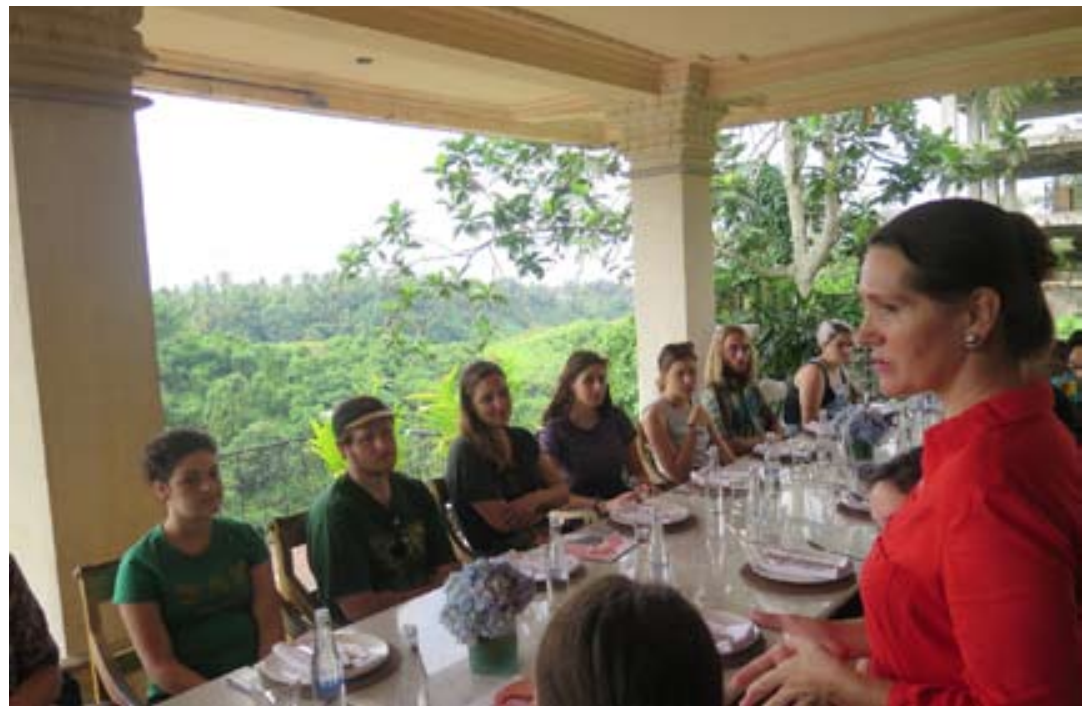

Figure 3 Beautiful Ubud View from a restaurant (Photo Darma Putra)

By all means, in a situation of free trade with the increasingly tight competition, the weaker parties will be more marginalized even eliminated from in the market competition. Therefore, people will try to avoid the marginalization in various ways, including by establishing partnerships with foreign parties. The mastery and use of foreign languages become increasingly important, so, by the same token, the use of local languages is gradually ignored.

As described above, the ideological interests underlie the marginalization of Balinese language. There are some interests of Balinese people that motivate them to use other languages, such as Indonesian and foreign languages, such as English, and others. One of them is the interest relating to the aspect of economy they are in. This is evidence from the information given by I Made Subrata in the village of Ubud, as stated above, that "...... if it is for business even though at Puri (Balinese palace), it must be informal". Furthermore I Made Subrata also said that to manage his hostelry, it needs employees who can speak English communicatively. It means the ability to speak English is a necessity even for employees of hostelry so that they can carry out their duties well.

It is imaginable that the employees or people working on differentsub-sectors of tourism, such ashotels, restaurants, art shops, 
and so on have strong intention to master English. Even the need to master English is required for security officers, shop assistants, street vendors, , and many others who run their economic activities in the areas of tourism and communicate with English speaking tourists. Therefore, it is no wonder that not only the employees or entrepreneurs working in tourism sector who frequently use foreign languages, but also people who will work or apply for job in tourism, because one of the requirements is the mastery of English and/or other foreign languages. Without having sufficient ability in English, it can be imagined that people would find it hard to work in tourism sector, especially in communicating with foreign tourists. This condition is determined by the parameters of interconnection, interaction, and interdependence. Seemingly, it has become knowledge in public, especially in the tourist areas. This is evidence from English language training activities which grow and spread flourishingly. As known, English language training, besides organized by the English training centers with official license, it is also held by pasraman under the organization of pakraman village or customary village. In this regard Made Bawa in Ubud confirms that in pasraman of pakraman village, children are given English course.

The rise of English language training and lack of interest for Balinese language training to be held among Balinese people signify that the interest in English language is far higher than the interest in Balinese language. Besides relating to the aspect of economy, the interest of Balinese people to use non Balinese language is also associated with psycho-cultural aspects, namely the great will which is commonly called desire. The desire is reflected in the use of other languages (not Balinese language), especially the desire to earn material or money. In order to earn money people need to work and to get a job that matches his main choice (job preference) they feel obliged to be able to speak Indonesian and / or a foreign language. Therefore, they will have the ability to speak non Balinese language to fulfill their desire to earn money. By having money they can build an image that they are wealthy meaning that they have the ability to earn money. The ability is associated with the use of non Balinese language in communication.

Both the interests of Balinese people relating to aspects of economy as well as psycho-cultural aspects in the sense as described above are basically closely related to the ideology that 
underlies and motivates them to use other languages (not Balinese language). Based on the ideology of capitalism that embodies the ideology of materialism and sort of it, Balinese people continually produce desires, interests, and needs. In such circumstances they strive to meet the demands of the growing needs in various ways, including by earning money using language as the main capital. The perceived potential language is foreign language, as the result, foreign language is an idol for them. The more they can speak foreign language, the prouder they are, and vice versa. Therefore, it is not surprising if they use foreign language, not only in communicating with foreigners, but also in communicating with fellow Balinese. In addition, they also realize that many people are amazed by those who can speak foreign languages, and therefore they then attempt to show their ability in foreign languages. So that, seemingly there is the nuance of image and/or popularity building in the use of foreign languages. The fact that the use of Balinese language is less prestigious so no wonder fewer and fewer people like to use Balinese language.

One of the events promoting tourism of Ubud village, some international events have been regularly held such as Ubud Writers and Readers Festival. This Festival becomes an event where writers from foreign countries and from Indonesia gather and it is also a routine and annual event that prefers the use of foreign languages in order to support the activities.

\section{Conclusion}

Based on the explanation above, it can be concluded that the village of Ubud is one area of tourism in Bali where various ethnic groups of settlers live in the village for example, Chinese, Javanese, Sundanese, Sasak, Bugis, and others. In addition, the village of Ubud is also inhabited by expatriates who deliberately come to Bali and settle there. These conditions greatly affect the choice and use of language of the Balinese people at Ubud. English is the main choice of language of the people or expatriates apart from other European languages such as Italian, French, and Spanish. In the context of tourism, English, Italian, French, Spanish, Mandarin, Japanese, and Korean are very important because as foreign languages and international languages, these languages are used along side the use of Balinese and Indonesian language. 


\section{Acknowledgement}

I greatly appreciate the Rector of Udayana University for the funding to conduct research through Udayana University Research Centre. I also want to express special thanks to the head of village at Ubud, and the informants providing information about the discussed topics.

\section{REFERENCES}

Althusser, Louis. 2008. Tentang Ideologi : Marxisme Strukturalis, Psikoanalisis,Cultural Studies. Yogyakarta : Jalasutra.

Aminuddin, 2002. "Pendekatan Linguistik Kritis: Roger Flower", dalam AnalisisWacana dari Linguistik Sampai Dekonstruksi (K.Budiman, Penyunting). Yogyakarta: Kanal. Halaman 1-53.

Ardika, I Wayan. 2007. Pusaka Budaya \& Pariwisata. Denpasar: Pustaka Larasan.

Atmadja, Nengah Bawa. 2005. Bali pada Era Globalisasi: Pulau Seribu Pura Tidak Seindah Penampilannya. Singaraja (naskah tidak terbit).

Fill, Alwin dan Peter Muhlhausler (eds.). 2001. The ecolinguistics Reader. Language, Ecology, and Environment. London and New York: Continuun

Jorgensen, M. W. dan Louise J. Philips. 2007. Analisis Wacana: Teori danMetode. Yogyakarta : Jalasutra.

Keriana, I K. 2004."Campuran Kode dalam Penggunaan Bahasa Balipada Rapat Adat Desa Pakraman Kedewatan, Ubud, Gianyar." Tesis Jurusan Bahasa,IKIP Negeri Singaraja.

Mbete, Aron Meko. 2013. Penuntun Singkat Penulisan Proposal Penelitian Ekolinguistik. Denpasar: Vidia.

Satori, Djaman dan Aan Komariah. 2009. Metodologi Artikel Kualitatif. Bandung: Alfabeta.

Sutjiati Beratha, N. L., et al. 2013. Menangani Masalah Marginalisasi Bahasa Bali: Merancang Model Revitalisasi Bahasa Daerah di Bali. Research Report. Denpasar: UniversitasUdayana.

Sutjiati Beratha, N. L., et al. 2017. Ekologi Bahasa Bali di Kawasan Pariwisata di Bali. Research Report. Denpasar: UniversitasUdayana.

Takwin, Bagus. 2003. Akar-Akar Ideologi. Yogyakarta: Jalasutra.

Thompson, John B. 2007. Analisis Ideologi, Kritik Wacana Ideologi-ideologi Dunia (Haqqul Yaqin, penerjemah). Yogyakarta: IRCiSoD. 